\title{
IZRADA VIŠERAZINSKOG OPISA IZVORNOGA ARHIVSKOG GRA- DIVA ZA POTREBE STVARANJA FONDA HR-HDA-2023, SUKLADNO STRUČNIM MEĐUNARODNIM STANDARDIMA ISAD(G) I ISAAR(CPF)
}

Lana ŽAJA

Hrvatski državni arhiv

Zagreb, Marulićev trg 21

lzaja@arhiv.hr
UDK 930.253:630/635(497.5)“1971/1990““

Stručni rad

https://doi.org/10.31726/via.26.26.7

Članak opisuje izradu opisa izvornoga arhivskog gradiva Republičkog sekretarijata za poljoprivredu, prehrambenu industriju i šumarstvo i Republičkog komiteta za poljoprivredu i šumarstvo u gospodarstvenoj oblasti od 1971. do 1990. godine, prema arhivskom znanstvenom pristupu opisa dokumentacije od trenutka preuzimanja iste do konačnog pohranjivanja tematskih cjelina u za to propisane uvjete (Fond HRHDA-2023). Istraživanje povijesti navedenih institucija s opisom ustroja i sadržaja službenih dokumentacijskih cjelina izvornoga arhivskoga gradiva, neophodno je za izradu višerazinskog opisa od općeg ka posebnome, sukladno Općim međunarodnim normama za opis arhivskoga gradiva ISAD(G) i ISAAR(CPF).

Ključne riječi: Republički sekretarijat za poljoprivredu, prehrambenu industriju i šumarstvo SRH, Republički komitet za poljoprivredu i šumarstvo SRH, Hrvatski državnih arhiv, arhivistika, poslovna dokumentacija, izvorno arhivsko gradivo, ISAD(G), ISAAR(CPF)

Keywords: $\quad$ Republic Secretariat of Agriculture, Food Industry and Forestry of the Republic of Croatia, Republic Committee for Agriculture and Forestry of the Republic of Croatia, Croatian State Archives, archival science, business records, original archives, ISAD(G), ISAAR(CPF)

Parole chiave: Segretariato per l'agricoltura, l'industria alimentare e le politiche forestali della Repubblica Socialista di Croazia, Comitato per l'agricoltura e le politiche forestali della Repubblica Socialista di Croazia, Archivio di Stato della Croazia, archivistica, documentazione commerciale, materiale archivistico originale, ISAD(G),ISAAR(CPF) 


\section{UVOD}

Arhivska priprema za rad na izvornom trajnom gradivu i službenoj dokumentaciji Ministarstva poljoprivrede Republike Hrvatske započela je 2009. godine temeljem ugovora o suradnji između Hrvatskog državnog arhiva i Ministarstva poljoprivrede, ribarstva i ruralnog razvoja i Ministarstva regionalnog razvoja, šumarstva i vodnog gospodarstva.

Prilikom sređivanja službenih spisa proveden je postupak vrednovanja ${ }^{1}$ operativnih dokumenata i trajnoga arhivskoga gradiva kojim je procijenjena vrijednost zapisa u skladu sa značajem i djelatnošću Ministarstva, interesom javnosti za uvid u službeno gradivo i vrijednošću gradiva za uvid u djelatnosti tijekom kojih je gradivo nastalo, kao i ukupnim značenjem za kulturu, povijest i druge znanosti. Izrađen je plan sređivanja poslovne dokumentacije prema stvarateljima ${ }^{2}$ iz razdoblja 1971. - 1995. Nakon sređivanja arhivski fond $^{3}$ Republičkog komiteta za poljoprivredu i šumarstvo je sadržavao 110 knjiga i 299 arhivskih kutija, te je 2010. godine provedeno arhivističko sređivanje i višerazinski opis gradiva prema zahtjevnim arhivističkim i stručnim ISAD $(\mathrm{G})^{4}$ i ISAAR $(\mathrm{CPF})^{5}$ standardima u konvencionalnom i digitalnom obliku. Hrvatski državni arhiv (dalje: HDA) preuzeo je fond (cjelokupnu dokumentaciju) 2011. godine od Ministarstva poljoprivrede, ribarstva i ruralnog razvoja.

\section{OPĆI KONTEKST STVARATELJA}

Sukladno ISAD $(G)$ koji uvažava mogućnost neovisne izrade i održavanja kontekstualnih obavijesti, kao i njihova povezivanja s ostalim obavijesnim elementima, koji se koriste za opis arhivskog gradiva pravila sređivanja izvornoga arhivskog gradiva su podijeljena na sedam područja opisa:

1. Područje identifikacije koje sadrži bitne obavijesti za identifikaciju jedinice opisa za ovaj fond na samom početku sadrži sljedeće:

\section{IDENTIFIKACIJA}

\section{Oznaka / Signatura:}

HR HDA 2023.

»Pravilnik o vrednovanju te postupku odabiranja i izlučivanja arhivskoga gradiva«, Narodne novine, (dalje: $N N$ ) 90/2002.

2 »Stvaratelj gradiva je tijelo javne vlasti, pravna ili fizička osoba, grupa osoba koja obavlja određenu djelatnost čijim djelovanjem nastaje dokumentarno i arhivsko gradivo«; čl. 3. »Zakona o arhivskom gradivu i arhivima«, u $N N, 61 / 2018$.

3 »Gradivo nastalo djelovanjem i radom tijela javne vlasti ili drugog stvaratelja čini cjelinu (arhivski fond) i u pravilu se ne može dijeliti«, čl. 7. »Zakona o arhivskom gradivu i arhivima«, u: $N N, 61 / 2018$.

4 ISAD (G): Opća međunarodna norma za opis arhivskog gradiva, 2. izd., Zagreb: HDA, 2001.

5 ISAAR (CPF): Međunarodna norma arhivističkog normiranog zapisa za pravne i fizičke osobe te obitelji, 2. izd., Zagreb: HDA, 2006. 
Naslov:

Kratica naslova:

Klasifikacija:

Vrijeme nastanka gradiva:

Razina opisa:

Količina:

Naziv stvaratelja:

Vrsta entiteta:

Razdoblje djelovanja:

Sjedište djelatnosti:

Normativni naziv:

Povijesni naziv:
REPUBLIČKI KOMITET ZA POLJOPRIVREDU I ŠUMARSTVO SOCIJALISTIČKE REPUBLIKE HRVATSKE

RKPŠ

A.5.1. Središnja državna tijela

1972-1990.

Fond

99 knjiga, 297 arhivskih kutija;

$30 \mathrm{~d} / \mathrm{m}$

REPUBLIČKI KOMITET ZA POLJOPRIVREDU I ŠUMARSTVO SOCIJALISTIČKE REPUBLIKE HRVATSKE

pravna osoba

1972-1990.

Zagreb

SR Hrvatska; Republički komitet za poljoprivredu i šumarstvo

Republički sekretarijat za prehrambenu industriju, poljoprivredu i šumarstvo Socijalističke Republike Hrvatske (1972-1979.); Republički komitet za poljoprivredu i šumarstvo Socijalističke Republike hrvatske (1979-1990.)

2. Područje konteksta koje sadrži obavijesti o porijeklu i sačuvanosti jedinice opisa $^{6}$

3. Područje sadržaja i ustroja koje sadrži obavijesti o predmetu i sređenosti jedinice opisa ${ }^{7}$

4. Područje uvjeta dostupnosti i korištenja koje sadrži obavijesti o dostupnosti jedinice opisa podrazumijeva sljedeće informacije:

Fond ima status javnog arhivskog gradiva te je dostupan svim korisnicima u skladu sa Zakonom o arhivskom gradivu i arhivima $(N N, 105 / 97)$ te Pravilnikom o korištenju arhivskog gradiva $(N N, 67 / 99)$. Najveći dio fonda čini javno arhivsko gradivo koje je za korištenje dostupno 30. godina nakon nastanka. $U$ fondu se također nalazi dokumentacija s oznakom tajnosti, čija je dostupnost ograničena i u postupanju s kojom se primjenjuju odredbe Zakona o tajnosti podataka $(N N, 79 / 2007)$ i Zakona o informacijskoj sigurnosti (NN, 79/2007). Dokumentaciju s oznakom tajnosti (strogo povjerljivo, povjerljivo) sadrži arhivska serija 2. Poljoprivredna politika i agroindustrijski kompleks. Ukoliko znanstveni razlozi zahtijevaju korištenje arhivskog gradiva proje isteka predviđenih rokova korištenje tog gradiva odobrava ravnatelj HDA uz obvezno prethodno pribavljeno mišljenje Hrvatskog arhivskog vijeća. Uvjeti objavljivanja ili umnožavanja određeni su Pravilnikom o radu

Vidi pod poglavljima uvod i povijest stvaratelja fonda

Vidi pod organizacijske jedinice i unutarnji ustroj 
Čitaonice Hrvatskog državnog arhiva, te Pravilnikom o korištenju arhivskog gradiva ( $N N$, 671999). Osnovne informacije o uvjetima objavljivanja ili umnožavanja gradiva dostupne su na mrežnim stranicama Hrvatskog državnog arhiva. O istima je potrebno konzultirati i djelatnike u Korisničkoj službi HDA. Jezik / pismo u gradivu: Gradivo je na hrvatskom jeziku. Pismo u fondu je latinica. Tvarne značajke i tehnički uvjeti: Papir. Nema znatnijih mehaničkih oštećenja na spisima nastalih prije preuzimanja u HDA. Evidencije predmeta upravnog postupka su restaurirane radi oštećenja uzrokovanog vlagom. Obavijesna pomagala: Kao obavijesna pomagala dijelom mogu poslužiti spisovodstvene evidencije.

5. Područje dopunskih izvora koje sadrži obavijesti o gradivu koje je u važnom odnosu s jedinicom opisa i to je bibliografija koja uključuje Šematizam državne uprave 1945. 1990. (1994.) drugo dopunjeno izdanje II dio, Narodne novine 31/71; 44/79; 33/83; 41/90.

6. Područje napomena koje sadrži posebne obavijesti i obavijesti koje ne mogu biti smještene u bilo koje drugo područje što znači da se prilikom citiranja gradiva fonda, navodi se oznaka zemlje, kratica ustanove, broj fonda, naziv fonda, potpuna signatura i naziv arhivske jedinice na primjer: HR-HDA-2023., RKPŠ SRH, 2.3.5. Nadležnost za imovinsko-pravne poslove

7. Područje kontrole opisa koje sadrži obavijesti o tome kako, kada i tko je izradio arhivistički opis. Uz osobne podatke o imenu mentora te pristupnika ispitu, ovaj inventar je izrađen 2014. godine, a temeljna svrha izrade je bila stručna radnja koja prethodi polaganju stručnog ispita iz arhivske struke, a što je utvrđeno Pravilnikom o uvjetima i načinu stjecanja stručnih zvanja u arhivskoj struci. ${ }^{8}$

Suputnik standarda ISAD(G) koji skrbi za uključivanje kontekstualnih obavijesti na bilo kojoj razini opisa arhivskog gradiva je norma ISAAR(CPF): Međunarodna norma arhivističkog normiranog zapisa za pravne i fizičke osobe te obitelji, čiji se arhivistički normirani zapisi koriste za opis pravne osobe, fizičke osobe ili obitelji kao jedinica u sustavu arhivističkog opisa, za kontrolu izrade i uporabe pristupnica u arhivističkim opisima te za bilježenje odnosa između različitih stvaratelja arhivskog gradiva između stvaratelja i gradiva koje je nastalo njihovim djelovanjem i/ili drugih izvora o njima ili koje su oni stvorili. Glavni elementi opisa za arhivistički normirani zapis organizirani su u četiri područja obavijesti:

1. Područje identifikacije u kojem je dana obavijest koja jednoznačno identificira stvaratelja koji se opisuje i definira normirane pristupnice za zapis navodi se naziv fonda, vrsta entiteta, razdoblje, normativni naziv, povijesni naziv te aktivnost (ne)djelovanja.

2. Područje opisa u kojem se daju dodatne relevantne obavijesti o prirodi, kontekstu i djelovanju entiteta koji se opisuje u polju povijesti stvaratelja fonda, sjedišta, djelatnosti i unutarnjeg ustroja/genealogije.

3. Područje veza u kojem su opisane veze s drugim pravnim i fizičkim osobama i/ili obiteljima opisano je prednicima i slijednicima stvaratelja.

$N N, 107 / 2010$ 
4. Područje kontrole u kojem je normirani zapis identificiran na jedinstven način i gdje je zabilježena obavijest o tome kako, kada i koja je ustanova stvorila i čuvala zapis utvrđen je u

nazivu arhivskog gradiva, identifikatoru tj. nazivu fonda, statusu zapisa koji može biti izmijenjena inačica, podrobnosti koja može biti djelomična ili potpuna, jezik opisa je hrvatski i pismo je latinica.

Primjeri fondova opisani Općom međunarodnom normom za opis arhivskoga gradiva $(\operatorname{ISAD}(\mathrm{G}))$ te Međunarodnom normom arhivističkoga normiranog zapisa za pravne i fizičke osobe te obitelji (ISAAR(CPF)) za opis povijesti stvaratelja gradiva se mogu pronaći u Nacionalnom arhivskom informacijskom sustavu (skr. NAIS) Hrvatskog državnog arhiva. ${ }^{9}$

\section{POVIJEST STVARATELJA FONDA}

Sabor Socijalističke Republike Hrvatske je na sjednicama Republičkog vijeća 15. srpnja 1971. i na sjednici Organizacionog političkog vijeća 15. srpnja 1971. donio »Zakon o izmjenama i dopunama Zakona u upravi«. ${ }^{10}$ Novim izmijenjenim Zakonom u sastavu Republičkih organa uprave ustrojeni su sekretarijati iz sljedećih oblasti:

1. Republički sekretarijat za unutrašnje poslove,

2. Republički sekretarijat za narodnu obranu,

3. Republički sekretarijat za pravosuđe i opću upravu,

4. Republički sekretarijat za financije,

5. Republički sekretarijat za industriju, trgovinu i zanatstvo,

6. Republički sekretarijat za pomorstvo, saobraćaj i veze,

7. Republički sekretarijat za poljoprivredu, prehrambenu industriju i šumarstvo,

8. Republički sekretarijat za urbanizam, građevinarstvo, stambene i komunalne poslove,

9. Republički sekretarijat za vodoprivredu,

10. Republički sekretarijat za prosvjetu, kulturu i fizičku kulturu,

11. Republički sekretarijat za narodno zdravlje i socijalnu zaštitu,

12. Republički sekretarijat za rad,

13. Republička geodetska uprava i

14. Republička uprava za imovinsko pravne poslove.

»Zakonom o organizaciji i djelokrugu republičkih organa uprave i republičkih organizacija« koji je Sabor SRH donio na sjednici Društveno političkog vijeća 24. srpnja i 20.

$9 \quad$ Primjer upisanog strukturiranog fonda u NAIS-u sukladno normi ISAAR(CPF). URL: http://arhinet. arhiv.hr/details.aspx?ItemId=3_9386 (10.10.2019.) 
rujna $1979 .{ }^{11}$ izvršena je reorganizacija republičkih organa uprave i republičke organizacije. Ustroj i nadležnost četiri sekretarijata nije promijenjen (Republički sekretarijat za unutrašnje poslove, Republički sekretarijat za narodnu obranu, Republički sekretarijat za pravosuđe i opću upravu i Republički sekretarijat za financije). Osam sekretarijata je reorganizirano u četrnaest komiteta:

1. Republički komitet za energetiku, industriju, rudarstvo i zanatstvo (bivši Republički sekretarijat za industriju, trgovinu i zanatstvo),

2. Republički komitet za pomorstvo, saobraćaj i veze (bivši Republički sekretarijat za pomorstvo, saobraćaj i veze),

3. Republički komitet za robni promet,

4. Republički komitet za turizam,

5. Republički komitet za poljoprivredu i šumarstvo (bivši Republički sekretarijat za poljoprivredu, prehrambenu industriju i šumarstvo),

6. Republički komitet za vodoprivredu (bivši Republički sekretarijat za vodoprivredu),

7. Republički komitet za građevinarstvo, stambene i komunalne poslove i zaštitu čovjekove okoline (bivši Republički sekretarijat za urbanizam, građevinarstvo, stambene i komunalne poslove),

8. Republički komitet za odnose s inozemstvom,

9. Republički komitet za prosvjetu, kulturu, fizičku i tehničku kulturu (bivši Republički sekretarijat za prosvjetu, kulturu i fizičku kulturu),

10. Republički komitet za znanost, tehnologiju i informatiku,

11. Republički komitet za zdravstvenu i socijalnu zaštitu (bivši Republički sekretarijat za narodno zdravlje i socijalnu zaštitu),

12. Republički komitet za boračka i invalidska pitanja,

13. Republički komitet za rad i zapošljavanje (bivši Republički sekretarijat za rad) i

14. Republički komitet za informiranje.

Republički komiteti osnivani su u onim oblastima u kojima je bilo potrebno osigurati koordiniranje i usklađivanje rada između više republičkih tijela uprave, društveno političkih zajednica, samoupravnih organizacija, zajednica i njihovih udruženja.

Sastav Republičkog komiteta kao i broj članova koje delegiraju odgovarajuće samoupravne organizacije i zajednice odnosno njihova udruženja utvrđivale su se odlukom Sabora SRH.

»Zakonom o izmjenama i dopunama Zakona o organizaciji i djelokrugu republičkih organa uprave i republičkih organa uprave i republičkih organizacija « ${ }^{12}$ imovinsko-pravne poslove iz dotadašnjeg djelokruga Republičkog komiteta za poljoprivredu i šumarstvo i Republičkog komiteta građevinarstvo, stambene i komunalne poslove i zaštitu čovjekove

\footnotetext{
$11 \quad N N, 44 / 1979$.

$12 N N, 33 / 1983$.
} 
okoline (koji se odnose na eksproprijaciju, korištenje građevinskog zemljišta, opseg prava vlasništva na nekretninama, imovinsko pravni dio komasacije i arondacije zemljišta, samovlasno zauzeće zemljišta u društvenom vlasništvu, promet zemljišta i zgrada, imovinsko pravni dio agrarnih operacija, podruštvljavanje zemljišta i imovinu stranih državljana) preuzeo je Republički sekretarijat za pravosuđe i upravu (od 1. siječnja 1984.).

Od 5. listopada 1990. »Zakonom o ustrojstvu republičke uprave $\ll^{13}$ utvrđuje se ustrojstvo i djelokrug ministarstava i zavoda:

1. Ministarstvo energetike i industrije,

2. Ministarstvo financija ( bivši Republički sekretarijat za financije),

3. Ministarstvo informiranja (bivši Republički komitet za informiranje),

4. Ministarstvo inozemnih poslova (bivši Republički komitet za odnose s inozemstvom),

5. Ministarstvo iseljeništva,

6. Ministarstvo obrane (bivši Republički sekretarijat za narodnu obranu),

7. Ministarstvo pravosuđa i uprave (bivši Republički sekretarijat za upravu i pravosude),

8. Ministarstvo prometa i veza (bivši Republički komitet za pomorstvo, saobraćaj i veze),

9. Ministarstvo pomorstva (bivši Republički komitet za pomorstvo saobraćaj i veze),

10. Ministarstvo poljoprivrede i šumarstva (bivši Republički komitet za poljoprivredu i šumarstvo),

11. Ministarstvo prosvjete i kulture (bivši Republički komitet za prosvjetu, kulturu, fizičku i tehničku kulturu),

12. Ministarstvo rada i socijalne skrbi (bivši Republički komitet za rad i zapošljavanje),

13. Ministarstvo trgovine (bivši Republički komitet za robni promet),

14. Ministarstvo turizma,

15. Ministarstvo unutarnjih poslova (bivši Republički sekretarijat za unutrašnje poslove),

16. Ministarstvo zaštite okoliša, prostornog uređenje i graditeljstva (bivši Republički komitet za građevinarstvo, stambene i komunalne poslove i zaštitu čovjekove okoline),

17. Ministarstvo vodoprivrede (bivši Republički komitet za vodoprivredu),

18. Ministarstvo zdravstva (bivši Republički komitet za zdravstvenu i socijalnu zaštitu) $\mathrm{i}$

19. Ministarstvo znanosti i tehnologije.

$13 \quad N N, 41 / 1990$. 


\section{ORGANIZACIJSKE JEDINICE I UNUTARNJI USTROJ}

Republički komitet za poljoprivredu i šumarstvo (Republički sekretarijat za poljoprivredu, prehrambenu industriju i šumarstvo 1971. - 1979., Republički komitet za poljoprivredu i šumarstvo 1979.-1990., Ministarstvo poljoprivrede i šumarstva 1990.) osigurava provođenje zakona, propisa i mjera u oblasti poljoprivrede, veterinarstva, ribarstva, prehrambene i duhanske industrije, šumarstva i lovstva.

Zadaća je Komiteta bila da prati i analizira uvjete privređivanja i djelovanje privrednog sustava i mjera u tim oblastima, prati rad zemljoradničkog zadrugarstva, prati i analizira kretanje šumarske privrede i razvoj institucija u oblasti poljoprivrede, veterinarstva, ribarstva, šumarstva i lovstva.

Komitet je u upravnim stvarima rješavao sporove te je obavljao inspekcijske poslove koji se odnose na poljoprivredu, veterinarstvo, ribarstvo, šumarstvo i lovstvo, kao i druge upravne poslove određene zakonom. Od 1979. Komitet je preuzeo dio poslova Republičke uprave za imovinsko-pravne poslove (1971. - 1979.), koji su se odnosili na poljoprivredno i šumsko zemljište.

Navedene poslove Komiteta iz oblasti imovinsko-pravnih odnosa 1. siječnja 1984. je promjenom nadležnosti preuzela Uprava za imovinsko-pravne poslove (1983.-1990.) u sastavu Republičkog sekretarijata za pravosuđe i upravu.

Tijela su u sastavu Komiteta ${ }^{14}$ bila:

1. Uprava za veterinarstvo (1971. - 1990.),

2. Poljoprivredni inspektorat / Inspektorat za poljoprivredu i ribarstvo - preuzet je 1971. od Republičkog sekretarijata za privredu (1965. - 1979.), od 1979. djeluje kao Inspektorat za poljoprivredu i ribarstvo u sastavu komiteta (1979. - 1990.), od listopada 1990. Inspektorat je ukinut, a njegove poslove su preuzeli Ministarstvo poljoprivrede $\mathrm{i}$ šumarstva (inspekcijske poslove koji se odnose na poljoprivredu i slatkovodno ribarstvo) i Ministarstvo pomorstva (inspekcijski poslovi za morsko ribarstvo),

3. Inspektorat za šumarstvo i lovstvo - preuzet je 1971. od Republičkog sekretarijata za privredu, od listopada 1990. Inspektorat je ukinut, a njegove poslove preuzima Ministarstvo poljoprivrede i šumarstva direktno (inspekcijske poslove za poljoprivredu i slatkovodni ribarstvo, šumarstvo i lovstvo).

Prema »Pravilniku o unutrašnjoj organizaciji Republičkog sekretarijata za poljoprivredu, prehrambenu industriju i šumarstvo« iz 1976. utvrđene su četiri organizacijske jedinice i tri tijela (organa) u sastavu:

\begin{tabular}{|l|l|}
\hline Organizacijske jedinice & 1. Kabinet republičkog sekretara \\
\hline & $\begin{array}{l}\text { 2. Stručna služba za poljoprivredu, prehrambenu i duhansku } \\
\text { industriju, šumarstvo, lovstvo i ribarstvo }\end{array}$ \\
\hline & 3. Stručna služba za pravne poslove \\
\hline
\end{tabular}

14 Opis preuzet iz izvornika normativnih akata općih poslova o unutrašnjoj organizaciji i načinu rada Republičkog komiteta za poljoprivredu i šumarstvo (Fond HR-HDA-2023.). 


\begin{tabular}{|l|l|}
\hline & 4. Služba za opće poslove \\
\hline Tijela u sastavu & 1. Uprava za veterinarstvo \\
\hline & 2. Poljoprivredni inspektorat \\
\hline & 3. Inspektorat za šumarstvo i lovstvo. \\
\hline
\end{tabular}

Prema »Pravilniku o unutrašnjoj organizaciji Republičkog komiteta za poljoprivredu i šumarstvo« utvrđeno je šest organizacijskih jedinica i tri tijela (organa) u sastavu:

\begin{tabular}{|l|l|}
\hline Organizacijske jedinice: & 1. Kabinet predsjednika Komiteta \\
\hline & $\begin{array}{l}\text { 2. Služba za tekuća ekonomska, sistemska i razvojna pitanja u } \\
\text { poljoprivredi i prehrambenoj industriji }\end{array}$ \\
\hline & $\begin{array}{l}\text { 3. Služba za upravno pravne i stručne poslove u poljoprivredno } \\
\text { prehrambenoj industriji }\end{array}$ \\
\hline & 4. Služba za šumarstvo, lovstvo i preradu drveta \\
\hline & $\begin{array}{l}\text { 5. Odjel za zemljišno imovinsko pravne poslove do siječnja 1984. } \\
\text { kad te poslove preuzima Republički sekretarijat za pravosuđe i } \\
\text { upravu }\end{array}$ \\
\hline Tijela u sastavu: & 6. Odjel za poslove opće narodne obrane i društvene samozaštite \\
\hline & 1. Uprava za veterinarstvo \\
\hline & 2. Poljoprivredni inspektorat \\
\hline & 3. Inspektorat za šumarstvo i lovstvo. \\
\hline
\end{tabular}

\section{STRUKTURIRANJE POSLOVNE DOKUMENTACIJE U ARHIVSKI FOND, SERIJE I PODSERIJE}

Arhivsko gradivo u nastajanju ima svoj vlastiti izvorni red koji se temelji na specifičnim djelatnostima institucije, a u kojem se najbolje očituje poslovanje. Struktura veza između serija, dosjea, dokumenata i spisa prikazana je u fondu koji sadrži zakone i prijedloge zakona, informacije, programe i analize privrednih kretanja, kao i dokumentaciju o financiranju agroindustrijskog kompleksa, te izvještaje o problematici u prehrambenoj, mljekarskoj i duhanskoj industriji, zatim spisovodstvene evidencije povjerljivih predmeta, upravnih i neupravnih postupaka.

Značajnu cjelinu fonda čine izvještaji o radu, analize i programi razvoja specifičnih područja poljoprivrede, stočarstva, ribarstva, šumarstva i lovstva, te veterinarstva, kao i dokumentacija o obavljanju poljoprivrednih, ribarskih i veterinarskih inspekcijskih nadzora.

Dio gradiva se odnosi na dokumentaciju u vezi s izgradnjom energetskih, industrijskih postrojenja, te prometnica, zatim razne obavijesti o donošenju zakona i ostalih prijedloga zakona koji reguliraju područje vodoprivrede, zaštite okoliša općenito, kao i na područje zaštite okoliša od elementarnih nepogoda.

$\mathrm{U}$ fondu se također dio dokumentacije odnosi na zemljišno-imovinsko-pravne odnose s predmetnim spisima, rješenjima, žalbama, molbama predstavkama i pritužbama raznih 
tijela i građana, te izvještaje i analize provođenja zakona o promjenama strukture zemljišnog vlasništva.

U fondu je sadržana dokumentacija i dosjei zaposlenika o polaganju stručnih ispita za veterinarskog, šumarskog i poljoprivrednog inspektora, kao i registri i evidencije upravnih i neupravnih postupaka za izdavanje dozvola za obavljanje stručnog nadzora.

Dio gradiva fonda čini dokumentacija s oznakom tajnosti primljena od drugih saveznih i republičkih tijela uprave.

Tijekom sređivanja gradiva provedeno je izlučivanje sukladno »Pravilniku o vrednovanju te postupku odabiranja i izlučivanja arhivskoga gradiva« (uništavanje bezvrijedne dokumentacije) registraturnog gradiva prema arhivističkim standardima i po postupku predviđenom za izlučivanje temeljem »Odluke HDA« (Klasa: 036-04/09-01/10, Urbroj: 569-19-09-4, 16. studenoga 2009. godine).

Arhivski fond HR-HDA-2023. sadrži gradivo nastalo radom Republičkog sekretarijata za poljoprivredu, prehrambenu industriju i šumarstvo (1972. - 1979.) i Republičkog komiteta za poljoprivredu i šumarstvo (1979. - 1990.).

Prije preuzimanja djelatnici HDA sredili su gradivo, proveli izlučivanje i izradili sumarni popis. Tom prilikom fond je podijeljen u 10 serija $^{15}$ :

1. Organizacija upravnih i stručnih poslova,

2. Imovinsko pravni odnosi u vezi sa zemljištem,

3. Poljoprivreda,

4. Stočarstvo,

5. Veterinarstvo,

6. Ribarstvo,

7. Šumarstvo,

8. Lovstvo,

9. Klasificirani predmeti i

10. Organizacija općih i administrativnih poslova.

Nije preuzeta serija »Financijsko-računovodstveni poslovi« koja sadrži završne račune $\mathrm{i}$ isplatne liste i personalne dosjee zaposlenika iz razdoblja 1972. - 1989.

U HDA je 2014. obavljena revizija strukture fonda. Tijekom tog postupka formirane su konačne serije i podserije, određene signature svih arhivskih jedinica, propisno označene kutije i knjige te je izrađeno obavijesno pomagalo.

Dokumentaciju s oznakom tajnosti (strogo povjerljivo, povjerljivo) sadrži serija »Poljoprivredna politika i agroindustrijski kompleks«. Serije »Šumarstvo« i »Lovstvo« spojene su u jednu seriju i temeljem navedenog oblikovano je sljedećih devet serija:

1. Organizacija rada i upravljanje Komitetom,

15 ISAD (G). »U arhivističkoj praksi PODRUČJE KONTEKST: 3.2.1 Naziv stvaratelja, 3.2.2 Upravna povijest / biografski podaci, 3.2.4 Povijest arhivskog fonda, 3.2.5 Način preuzimanja ili predaje«. 
2. Poljoprivredna politika i Agroindustrijski kompleks,

3. Zemljišni imovinsko-pravni odnosi,

4. Infrastruktura:

Zaštita okoliša,

Vodoprivreda,

Elementarne nepogode,

5. Poljoprivreda,

6. Ribarstvo,

7. Stočarstvo,

8. Sumarstvo i lovstvo te

9. Veterinarstvo i zdravstvena ispravnost namirnica.

\section{Opis organizacija poslovne dokumentacije strukturirane prema serijama}

Opisivanje zapisa na razini serije kako bi se osiguralo da su zapisi različitog podrijetla odvojeni, pružila je alternativu katalogizaciji rukopisa na razini predmeta. ${ }^{16}$ Praksa provenijencije ima dva glavna koncepta: »respect des fonds« (hrv. poštivanje fonda) i »izvorni poredak» izvornoga arhivskoga gradiva. »Respect des fonds« proizlazi iz uvjerenja da zapisi koji ulaze u arhiv imaju bitnu vezu s pravnom osobom ili institucijom koji ih je stvorio i koristio. Arhivisti smatraju da su svi zapisi koji potječu od određene administrativne jedinice (bilo one bivše ili još uvijek postoje) zasebna arhivska skupina, ili ,fondovi“،, te nastojati sačuvati i opisati zapise u skladu s tim, s iznimnom pažnjom na dokaze o tome kako su bili organizirani i održavani u vrijeme kada su stvoreni. Prvenstveno ovim načelom provenijencije ili podrijetla je sređivan ovaj fond. U dokumentaciji serije »Organizacije rada i upravljanja Komitetom« sadržani su Pravilnici o unutrašnjoj organizaciji rada, spisi, dokumenti i razne informacije vezane za opće poslove Komiteta, izvještaje i materijale sa sjednica o informacijama općih poslova Komiteta i nadzoru samoupravnih tijela, rješenja o raspoređivanju na radna mjesta i plaćama, rješenja vezano uz molbe, preporuke i zahtjeve o dodjeli stanova. Serija sadrži povjerljive evidencije: urudžbene zapisnike i spisovodstvene evidencije, upisnike, popise akata i kazala predmeta upravnih i neupravnih postupaka. Sadržaj dosjea i spisa je raspoređen unutar sljedećih arhivskih jedinica:

1. Organizacija rada Komiteta,

2. Programi rada i izvještaji Komiteta,

3. Rad samoupravnih tijela Komiteta,

5. Normativni akti Komiteta,

5. Rad tijela u sastavu republičke uprave,

6. Ljudski resursi, rad i radni odnosi,

16 Luke J. Gilliland-Swetland, (1991). "The Provenance of a Profession: The Permanence of the Public Archives and Historical Manuscripts Traditions in American Archival History," American Archivist 54. no. 2. str. 161. 


\section{Dodjela stanova $\mathrm{i}$}

8. Spisovodstvene evidencije.

Cjelina »Poljoprivredna politika i Agroindustrijski kompleks« sadrži propise, programe rada, izvještaje o radu i poslovanju. Dio dokumentacije sadrži informacije i prijedloge programa o ekonomskim, financijskim i razvojnim pitanjima u poljoprivredi i prehrambenoj industriji. Serija obuhvaća programe i izvještaje o tekućim, financijskim i planskorazvojnim mjerama koje se odnose na ekonomski položaj, te razvoj i planske projekcije poljoprivrede i prehrambene industrije. Dio serije sadrži osobne podatke pristupnika za stručne ispite inspektora, te korespondenciju s organizacijama s područja poljoprivrede i suradnju s inozemstvom. Serija sadrži informacije o organizaciji i obavljanju poslova narodne obrane, zaštite i međunarodne suradnje, podatke kojima se osiguravaju svi uvjeti rada Komiteta. U ovoj seriji su i povjerljivi predmeti koji sadrže podatke o narodnoj obrani s oznakom tajnosti, a odloženi su prema tekućem broju unutar kalendarske godine. Sadržaj dosjea i spisa je raspoređen unutar sljedećih arhivskih jedinica:

1. Propisi iz područja agroindustrije,

2. Koordinacija poljoprivredne politike,

3. Zastupnička pitanja o privrednim kretanjima,

4. Agroindustrijski kompleks,

5. Stručni ispiti za veterinarskog, šumarskog i poljoprivrednog inspektora,

6. Korespondencija s tijelima i organizacijama s područja poljoprivrede,

7. Informacije o suradnji s inozemstvom i

8. Povjerljivi predmeti.

»Zemljišni imovinsko-pravni odnosi« je serija koja sadrži propise i rješenja vezana za zemljišne imovinsko pravne poslove, a koji se odnose na: sigurno provođenje zakona $\mathrm{i}$ drugih propisa kojima se uređuju imovinski odnosi na poljoprivrednom zemljištu, šumama i šumskom zemljištu, a naročito na prava vlasništva nad tim nekretninama, komasaciju i arondaciju zemljišta, uzurpaciju zemljišta u društvenom vlasništvu, agrarnu reformu i kolonizaciju, te poljoprivredni zemljišni fond.

Na zakonskom pitanju reguliranja poljoprivrednog zemljišta radilo se pet godina. »Prijedlog Zakona« usvojen je u Saboru u srpnju 1979., a »Nacrt Zakona« upućen je na javnu raspravu. Problematika poljoprivrednog zemljišta bila je predmet zanimanja šire javnosti, te je izvještaj radne grupe o rezultatima te javne rasprave prihvaćen u Saboru u svibnju 1980. Na sjednici u travnju 1984. Izvršno vijeće Sabora utvrdilo je konačan tekst »Prijedloga zakona o poljoprivrednom zemljištu«.

Organizacijske jedinice nadležne za rješavanje ovih predmeta bile su: Kabinet/Komitet, Odjel za poljoprivredno i šumsko zemljište i Odjel za poljoprivredno i šumsko zemljište i imovinsko-pravne odnose. Sadržaj dosjea i spisa je raspoređen unutar sljedećih arhivskih jedinica:

1. Propisi iz područja zemljišnih imovinsko-pravnih poslova, 
2. Izvještaji i analize iz područja zemljišnih imovinsko-pravnih odnosa te

3. Imovinsko-pravne mjere i promjene prava vlasništva.

Serija »Infrastruktura, zaštita okoliša, vodoprivreda i elementarne nepogode« sadrži spise o sudjelovanju članova Komiteta u radu određenih radnih grupa za pružanje pomoći društveno političkim zajednicama kod donošenja prostornih planova i provedbi zaključaka i smjernica Sabora za zaštitu građevinskog zemljišta, za suzbijanje uzurpacije poljoprivrednog i šumskog zemljišta, te zaštitu čovjekove okoline. Također sadrži spise o utvrđivanju šteta u poljoprivredi nastalih zbog elementarnih nepogoda kao što su oluja, tuča, poplava i sl., te prijedloge mjera za njihovu sanaciju. Dio serije sadrži predmetne spise o izgradnji energetskih, industrijskih postrojenja i prometnica, te informacije o davanjima suglasnosti za izgradnju, dogradnji i rad objekata. Serija sadrži propise i normativne akte, izvještaje i analize razvoja privrede, kao i predmete u kojima se regulira područje zaštite od elementarnih nepogoda. Sadržaj dosjea i spisa je raspoređen unutar sljedećih arhivskih jedinica:

1. Izgradnja infrastrukturnih objekata,

2. Zaštita okoliša,

3. Vodoprivreda $\mathrm{i}$

4. Elementarne nepogode.

»Poljoprivreda« je serija koja obuhvaća propise, izvještaje i analize tekućih ekonomskih, sistemskih i razvojnih pitanja u poljoprivredi i prehrambenoj industriji. Sadrži također spise o poljoprivrednoj proizvodnji, sjemenarstvu i vinogradarstvu, planove $\mathrm{i}$ analize tekućih, planskih razvojnih mjera koje se odnose na ekonomski položaj, razvoj i planske projekcije poljoprivrede i prehrambene industrije. Dio serije sadrži izvještaje i informacije o razvoju poljoprivrede, izvještaje o radu inspekcijske kontrole, propise o iskorištavanju poljoprivrednog zemljišta, kontroli kvalitetnih umjetnih gnojiva, proizvodnji poljoprivrednog sjemena i sadnog materijala, vina i drugih alkoholnih pića od mošta i vina. Serija obuhvaća analize i izvještaje o proizvodnji duhana, stočne hrane, zaštiti poljoprivrednog bilja od bolesti i štetočina, te propise o mjerama za unapređenje stočarstva i premije za kravlje i ovčje mlijeko i vunu. Sadržaj dosjea i spisa je raspoređen unutar sljedećih arhivskih jedinica:

1. Propisi iz područja poljoprivrede,

2. Izvještaji i analize iz područja poljoprivrede,

3. Razvoj poljoprivrede,

4. Sjemenarstvo,

5. Vinogradarstvo i vinarstvo,

6. Zaštita bilja,

7. Umjetna gnojiva $\mathrm{i}$

8. Poljoprivredni inspekcijski nadzor. 
Serija »Ribarstvo« sadrži propise, izvještaje i analize, kao i dokumente o provedbi zakona u morskom i slatkovodnom ribarstvu, te dokumentaciju o izgradnji i usavršavanju metoda rada inspekcije iz oblasti ribarstva. Sadržaj dosjea i spisa je raspoređen unutar sljedećih arhivskih jedinica:

1. Propisi iz područja ribarstva,

2. Izvještaji i analize iz područja ribarstva,

3. Razvoj i unapređenje ribarstva,

4. Morsko ribarstvo,

5. Slatkovodno ribarstvo,

6. Ribarski inspekcijski nadzor $i$

7. Upravni postupak upisa za izdavanje dozvola za natjecanja u sportskom ribolovu.

Cjelina »Stočarstvo« je serija koja obuhvaća propise, spise i planove organizacije rada, programe za poticanje razvoja stočarstva, izvještaje i analize unapređenja uzgojnih i selekcijskih centara, kao i izvještaje o potraživanju financijskih sredstava za reprodukciju različitih vrsta stoke, te podatke o uvozu i izvozu stoke. Sadržaj dosjea i spisa je raspoređen unutar sljedećih arhivskih jedinica:

1. Propisi iz područja stočarstva,

2. Izvještaji i analize iz područja stočarstva,

3. Razvoj i unapređenje stočarstva,

4. Razvoj konjogojstva i

5. Upravni postupak upisa za proizvođače kvalitetne rasplodne stoke.

Serija »Šumarstvo i lovstvo《 sadrži predmete iz područja šumarstva i lovstva iz nadležnosti Uprave za šumarstvo i lovstvo i predmete o inspekcijskim poslovima iz nadležnosti Inspektorata za šumarstvo i lovstvo. Sadrži propise, izvještaje i analize u kojima se predlažu tekuće ekonomske smjernice koje se odnose na plan i razvoj zaštite šuma. Serija sadrži analize i izvještaje nastale radom tijela šumarske i lovne inspekcije u zajednici općina i općinskih organa šumarske i lovne inspekcije u skladu sa zakonom o upravi, kao i izgradnji i unapređenju metoda rada iz oblasti šumarstva i lovstva. Dokumentacija Inspektorata za šumarstvo i lovstvo prati primjenu propisa u provođenju inspekcijskog nadzora $u$ oblastima šumarstva, lovstva, zaštiti bilja od biljnih bolesti i štetnika.

Predmetni spisi su odloženi uglavnom kronološki po godinama, a unutar njih su složeni prema rednom broju iz evidencije. Sadržaj dosjea i spisa je raspoređen unutar sljedećih arhivskih jedinica:

1. Propisi iz područja nadzora šumarstva i lovstva,

2. Izvještaji i analize iz područja šumarstva i lovstva,

3. Nadzor šumskih i lovnih područja,

4. Inspektorat za šumarstvo i lovstvo,

5. Rješenja za pravo prijenosa upravljanja šumskim zemljištem i 
6. Upravni postupci upisa iz nadležnosti Uprave za šumarstvo i lovstvo (UP I).

»Veterinarstvo i zdravstvena ispravnost namirnica« je serija koja obuhvaća propise, informacije i analize za provedbe mjera o zaštiti životinja od zaraznih bolesti. Dokumentacija uprave za veterinarstvo je vezana za rješavanje prava i obveza građana i drugih organizacija u oblasti suzbijanja opasnih stočnih zaraza kao i prometa stoke s inozemstvom. Spisi upravnog nadzora sadrže dokumentaciju o nadzoru nad veterinarskim organizacijama koje obavljaju poslove od društvenog interesa u oblasti veterinarstva. Dio serije sadrži i dokumentaciju o radu veterinarske inspekcije, izvještaje o nadzoru rada veterinarske organizacije, spise o obavljenim veterinarsko inspekcijskim nadzorima nad radom veterinarskih općina i veterinarskih stanica. Sadržaj dosjea i spisa je raspoređen unutar sljedećih arhivskih jedinica:

1. Propisi iz područja veterinarstva,

2. Organizacija rada veterinarske službe,

3. Suzbijanje zaraznih i nametničkih bolesti,

4. Zdravstvena ispravnost namirnica životinjskog porijekla,

5. Umjetno osjemenjivanje životinja i

6. Veterinarski inspekcijski nadzor.

\section{Strukturiranje fonda HR-HDA-2023.}

Elemente višerazinskog opis gradiva prema zahtjevnim arhivističkim i stručnim ISAD(G) i ISAAR (CPF) standardima trebalo je uvrstiti u strukturu od devet arhivskih serija i svaka je razvrstana i opisana u nižim podserijama:

1. Organizacija rada i upravljanje Komitetom:

1.1. Organizacija rada Komiteta,

1.1.1. Dopisi i informacije o organizaciji rada:

1.1.2. Imenovanja i odlikovanja,

1.1.3. Samoupravni sporazumi,

1.2. Programi rada i izvještaji Komiteta,

1.3. Rad samoupravnih tijela Komiteta,

1.4. Normativni akti Komiteta,

1.5. Rad tijela u sastavu republičke uprave:

1.5.1. Izvještaji o nadzoru nad radom općinskih tijela,

1.5.2. Informacije republičkih tijela uprave,

1.5.3. Izvještaji o stanju i problemima republičkih inspekcijskih službi,

1.5.4. Zapisnici o preuzimanju spisa Republičke uprave za imovinsko pravne poslove, 
1.5.5. Primopredajni predmeti ukinutih zajednica općina,

1.5.6. Korespondencija o nekretninama,

1.6. Ljudski resursi, rad i radni odnosi,

1.7. Dodjela stanova:

1.7.1. Pravilnici i informacije,

1.7.2. Odluke i preporuke za dodjelu stanova,

1.7.3. Ugovori i molbe za kredit,

1.7.4. Ugovori o dodjeli kredita,

1.8. Spisovodstvene evidencije:

1.8.1. Evidencije povjerljivih predmeta,

1.8.2. Evidencije predmeta upravnog postupka prvog stupnja,

1.8.3. Evidencije predmeta neupravnog postupka,

2. Poljoprivredna politika i agroindustrijski kompleks:

2.1. Propisi iz područja agroindustrije,

2.2. Koordinacija poljoprivredne politike,

2.3. Zastupnička pitanja o privrednim kretanjima,

2.4. Agroindustrijski kompleks:

2.4.1. Programi i analize privrednih kretanja,

2.4.2. Financiranje agroindustrijskog kompleksa,

2.4.3. Prehrambena industrija,

2.4.4. Mljekarska industrija:

2.4.4.1. Pravilnici i propisi,

2.4.4.2. Izvještaji i informacije,

2.4.4.3. Podaci o otkupu mlijeka,

2.4.5. Duhanska industrija,

2.5. Stručni ispiti za veterinarskog, šumarskog i poljoprivrednog inspektora,

2.6. Korespondencija s tijelima i organizacijama s područja poljoprivrede,

2.7. Informacije o suradnji s inozemstvom,

2.8. Povjerljivi predmeti,

3. Zemljišni imovinsko-pravni odnosi:

3.1. Propisi iz područja zemljišnih imovinsko-pravnih odnosa,

3.2. Izvještaji i analize iz područja zemljišnih imovinsko-pravnih odnosa,

3.3. Imovinsko-pravne mjere i promjene prava vlasništva:

3.3.1. Arondacija,

3.3.2. Eksproprijacija i uzurpacija, 


\subsubsection{Komasacija,}

4. Infrastuktura, zaštita okoliša, vodoprivreda i elementarne nepogode:

4.1. Izgradnja infrastrukturnih objekata:

4.1.1. Izgradnja prometnica,

4.1.2. Izgradnja industrijskih postrojenja,

4.1.3. Izgradnja energetskih postrojenja,

4.2. Zaštita okoliša,

4.3. Vodoprivreda:

4.3.1.Propisi iz područja vodoprivrede,

4.3.2. Projekti i programi razvoja vodoprivrede,

4.4. Elementarne nepogode:

4.4.1. Propisi iz područja zaštite od elementarnih nepogoda,

4.4.2. Izvještaji i analize iz područja šteta od elementarnih nepogoda,

5. Poljoprivreda:

5.1. Propisi iz područja poljoprivrede,

5.2. Izvještaji i analize iz područja poljoprivrede,

5.3. Razvoj poljoprivrede,

5.4. Sjemenarstvo:

5.4.1. Propisi iz područja sjemenarstva,

5.4.2. Izvještaji i analize iz područja sjemenarstva,

5.4.3. Upravni postupak upisa za uvoznike i proizvođače poljoprivrednog sjemena i sadnog materijala,

5.5. Vinogradarstvo $i$ vinarstvo:

5.5.1. Propisi iz područja vinogradarstva $i$ vinarstva,

5.5.2. Izvještaji $i$ analize iz područja vinogradarstva $i$ vinarstva,

5.5.3. Inspekcijski nadzor i ocjene stručnih komisija,

5.5.4. Upravni postupak upisa za označavanje vinskih sorti zaštitom geografskog porijekla,

5.6. Zaštita bilja:

5.6.1. Propisi iz područja zaštite bilja,

5.6.2. Izvještaji i analize iz područja zaštite bilja,

5.7. Umjetna gnojiva:

5.7.1. Propisi iz područja umjetnih gnojiva,

5.7.2. Upravni postupak upisa za korištenje umjetnih gnojiva,

5.7.3. Ekonomski i financijski izvještaji industrije umjetnih gnojiva, 
5.8. Poljoprivredni inspekcijski nadzor:

5.8.1. Programi rada i izvještaji,

5.8.2. Aprobacija,

6. Ribarstvo:

6.1. Propisi iz područja ribarstva,

6.2. Izvještaji i analize iz područja ribarstva,

6.3. Razvoj i unapređenje ribarstva,

6.4. Morsko ribarstvo,

6.5. Slatkovodno ribarstvo,

6.6. Ribarski inspekcijski nadzor,

6.7. Upravni postupak upisa za izdavanje dozvola za natjecanja u sportskom ribolovu,

7. Stočarstvo:

7.1. Propisi iz područja stočarstva,

7.2. Izvještaji i analize iz područja stočarstva,

7.3. Razvoj i unapređenje stočarstva,

7.4. Razvoj konjogojstva:

7.4.1. Izvještaji i analize iz područja konjogojstva,

7.4.2. Zapisnici i izvještaji Republičke komisije za konjogojstvo,

7.5. Upravni postupak upisa za proizvođače kvalitetne rasplodne stoke, 8. Šumarstvo:

8.1. Propisi iz područja nadzora šumarstva i lovstva,

8.2. Izvještaji i analize iz područja šumarstva i lovstva,

8.3. Nadzor šumskih i lovnih područja:

8.3.1. Zaštita šuma i lovišta,

8.3.2. Zaštita šuma od požara i biološka reprodukcija šuma,

8.3.3. Sječa šuma,

8.3.4. Organizacija lovnih područja,

8.3.5. Gospodarenje šumskim i lovnim područjima,

8.4. Inspektorat za šumarstvo i lovstvo,

8.5. Rješenja za pravo prijenosa upravljanja šumskim zemljištem,

8.6. Upravni postupak upisa iz nadležnosti Uprave za šumarstvo i lovstvo:

8.6.1. Upisnik proizvođača šumskog sjemena,

8.6.2. Prenamjena šumskog zemljišta,

8.6.3. Lovačke dozvole za unos životinja u lovna područja, 
9. Veterinarstvo i zdravstvena ispravnost namirnica:

9.1. Propisi iz područja veterinarstva,

9.2. Organizacija rada veterinarske službe,

9.3. Suzbijanje zaraznih i nametničkih bolesti,

9.4. Zdravstvena ispravnost namirnica životinjskog porijekla,

\subsection{Umjetno osjemenjivanje životinja:}

9.5.1. Izvještaji i analize iz područja umjetnog osjemenjivanja životinja,

9.5.2. Izvještaji o radu Središnjeg zavoda za razmnožavanje i uzgoj domaćih životinja, Zagreb-Zavod Križevci,

\subsection{Veterinarski inspekcijski nadzor:}

9.6.1. Izvještaji i analize o veterinarskom inspekcijskom nadzoru, 9.6.2. Godišnji izvještaji općinskih veterinarskih službi.

\section{Ustrojstvo uredskog poslovanja}

Uredsko poslovanje organizirano je prema propisima o uredskom poslovanju: »Uredbe o kancelarijskom poslovanju $\ll^{17} \mathrm{i} \gg$ Uputstva za izvršenje Uredbe $\ll_{,}^{18} \gg$ Naredbe o planu jedinstvenih arhivskih znakova za sve organe Uprave na teritoriju NR Hrvatske « ${ }_{19}^{19} \gg$ Uredbe o uredskom poslovanju«, ${ }^{20} \gg$ Uredbe o uredskom poslovanju« ${ }^{21} \gg$ Uputstva za izvršenje uredbe o uredskom poslovanju $\ll^{22}$. Spisi su evidentirani u propisane spisovodstvene ${ }^{23}$ evidencije, ali označavanje dovršenih predmeta arhivskim znakovima nije bilo dosljedno provedeno. ${ }^{24}$ Najveći dio predmeta, bez obzira na arhivske znakove, bio je odložen kao

17 Službeni list, 50/1957.

$18 \quad$ Na ist. mj.

$19 \quad N N, 71 / 1958$.

$20 \quad N N, 53 / 1974$.

$21 \quad N N, 38 / 1987$. i $42 / 1988$.

$22 \quad N N, 32 / 1988$. i 38/1988.

23 Spisovodstvo: »Upravljanje spisima je poslovna funkcija koja je u nekom obliku prisutna u svakoj ustanovi, poduzeću ili bilo kojoj drugoj vrsti organizacije.«; usp. Jozo IVANOVIĆ, Stručni ispit za zaštitu i obradu arhivskog gradiva - Priručnik, 2. izd., Zagreb: HDA, 2010., str 45.

24 Prednik Republičkom sekretarijatu za poljoprivredu, prehrambenu industriju i šumarstvo (1971.-1979.), odnosno Republičkom komitetu za poljoprivredu i šumarstvo (1979.-1990.) bio je Republički sekretarijat za privredu (1953.-1971.). Prema novom ustrojstvu republičke uprave koji je Sabor Republike Hrvatske donio na sjednici Vijeća općina 1990. i na sjednici Društveno političkog vijeća sljednik RKPŠ je Ministarstvo poljoprivrede i šumarstva. Fond ima status javnog arhivskog gradiva i dostupan je svim korisnicima u skladu sa »Zakonom o arhivskom gradivu i arhivima« te »Pravilnikom o korištenju arhivskog gradiva«. Javno arhivsko gradivo u pravilu je za korištenje dostupno trideset godina nakon nastanka. U fondu se također nalazi dokumentacija s oznakom tajnosti, čija je dostupnost ograničena i u postupanju s kojom se primjenjuju odredbe »Zakona o tajnosti podataka« $\mathrm{i} » Z$ Zakona o informacijskoj sigurnosti«.

Dokumentaciju s oznakom tajnosti (strogo povjerljivo, povjerljivo) sadrži arhivska serija »Državni, pravni i financijski poslovi komiteta«. Ukoliko znanstveni razlozi zahtijevaju korištenje arhivskog gradiva prije isteka predviđenih rokova, ravnatelj HDA može odobriti korištenje tog gradiva na način i pod 
jedinstvena serija »Opći spisi« prema tekućem rednom broju iz urudžbenog zapisnika. Dio predmeta nije imao upisan nikakav arhivski znak, dok je najveći dio predmeta naknadno bio označen arhivskim znakovima određene grupe. Svega nekoliko manjih cjelina bilo je formirano u posebne serije (uglavnom inspekcije). Prilikom arhivističkog sređivanja formirane su serije i podserije spisa prema djelatnostima i prema srodnosti sadržaja. Evidencije se moraju voditi istim redoslijedom kojim su stavljene tijekom službene aktivnosti ovog komiteta, a zapisi se ne smiju »umjetno« reorganizirati. Zapisi u očuvani u izvornom redoslijedu vjerojatnije će otkriti prirodu organizacija koje su ih stvorile i što je još važnije, redoslijeda aktivnosti iz kojih su su iste nastale.

\section{ZAKLJUČAK}

Organizacija i strukturiranje fonda sukladno međunarodnim arhivističkim standardima vrlo je složen proces. Prvo je trebalo definirati povijest nastanka Stvaratelja, a zatim strukturirati organizaciju djelatnosti. Prikupljene i obrađene podatke, trebalo je prezentirati u skladu s normama i standardima. Svaka serija i podserija znanja ima svoju strukturu (koja treba biti čvrsta i utemeljena na podacima i informacijama) i nudi obavijesno pomagalo u kojem se korisnici trebaju što lakše snalazili u tom, većini nepoznatom, okruženju. Strukturiranje fonda je jako širok i kompleksan pojam, te je nemoguće sve predložene smjernice upotrijebiti, a da odgovaraju svim predloženim zahtjevnim parametrima. Smisao opisa i organiziranja poslovne dokumentacije Komiteta je bio stvaranje Fonda HRHDA-2023. kao vrijednog povijesnog izvora informacija iz arhivskog gradiva i službenih podataka za različita istraživanja, iz područja povijesti, gospodarskog razvitka i istraživanja različitih političkih i ekonomskih prilika na području bivše SFRJ. U tom smislu cilj ovog rada je pružiti mogućnost uvida u stvaranje opsežnog fonda prikazujući okvir složenih struktura organiziranih tematskih područja, a samim time predstavlja i dodatan kvalitetan izvor za znanstvena istraživanja te daje i ogledan primjer izrade stručne radnje kao pripremu za polaganje ispita u stručno zvanje - arhivist.

\section{Arhivski fondovi:}

HR-HDA-2023. Republički komitet za poljoprivredu i šumarstvo 1971-1990

HR-HDA-280. Izvršno vijeće Sabora Socijalističke Republike Hrvatske

HR-HDA-1081. Sabor Socijalističke Republike Hrvatske

HR-HDA-1586. Republički sekretarijat za privredu

uvjetima koji jamče zaštitu javnih probitaka, odnosno privatnosti, prava i probitaka treće osobe, uz obvezno prethodno pribavljeno mišljenje Hrvatskog arhivskog vijeća. Uvjeti objavljivanja ili umnožavanja određeni su »Pravilnikom o radu Čitaonice Hrvatskog državnog arhiv«, te »Pravilnikom o korištenju arhivskog gradiva«. 
HR-HDA-1692. Republički sekretarijat za financije

HR-HDA-1947. Republički komitet za građevinarstvo, stambene i komunalne poslove i zaštitu čovjekove okoline

HR-HDA-1694. Republička komisija za popis i procjenu ratne štete

\section{Izvori:}

ISAAR (CPF): Međunarodna norma arhivističkog normiranog zapisa za pravne i fizičke osobe te obitelji, 2. izd., Zagreb: HDA, 2006.

ISAD (G): Opća međunarodna norma za opis arhivskog gradiva, 2. izd., Zagreb: HDA, 2001.

Narodne novine (Zagreb) 67/1999., 90/2002., 96/2002., 63/2004., 106/2007., 61/2008.

\section{Literatura:}

Ivanović, Jozo, Stručni ispit za zaštitu i obradu arhivskog gradiva - Priručnik, 2. izd., Zagreb: HDA, 2010.

Luke J. Gilliland-Swetland, (1991). ,The Provenance of a Profession: The Permanence of the Public Archives and Historical Manuscripts Traditions in American Archival History," American Archivist 54, no. 2. Str. 160-174.

Šematizam državne uprave 1945. - 1990. (1994.), 2. dop. izd., II. dio. 


\section{SAŽETAK}

\section{Izrada višerazinskog opisa izvornoga arhivskog gradiva za potrebe stvaranja Fonda HR-HDA-2023, sukladno stručnim međunarodnim standardima ISAD(G) i ISAAR(CPF)}

Članak opisuje izradu opisa izvornoga arhivskog gradiva Republičkog sekretarijata za poljoprivredu, prehrambenu industriju i šumarstvo i Republičkog komiteta za poljoprivredu i šumarstvo u gospodarstvenoj oblasti od 1971. do 1990. godine, sukladno međunarodnim normama za opis dokumentacije od trenutka preuzimanja iste do konačnog pohranjivanja tematskih cjelina u za to propisane uvjete (Fond HR-HDA-2023). Istraživanje povijesti navedenih institucija s opisom ustroja i sadržaja službenih dokumentacijskih cjelina izvornoga arhivskoga gradiva, neophodno je za izradu višerazinskog opisa od općeg ka posebnome, sukladno Općim međunarodnim normama za opis arhivskoga gradiva ISAD(G) i ISAAR(CPF). Smisao opisa i organiziranja poslovne dokumentacije Komiteta je bio stvaranje Fonda HR-HDA-2023. kao vrijednog povijesnog izvora informacija iz arhivskog gradiva i službenih podataka za različita istraživanja, iz područja povijesti, gospodarskog razvitka i istraživanja različitih političkih i ekonomskih prilika na području bivše SFRJ. Uz navedene međunarodne norme temeljne smjernice sređivanja fonda vođene su stručnim arhivističkim načelom provenijencije ili podrijetla.

\section{SUMMARY}

\section{Development of a multilevel description of the original archives for the purpose of creating the Fund HR-HDA-2023, in accordance with the professional international standards ISAD (G) and ISAAR (CPF)}

The article presents the development of a description of the original archival material of the Republic Secretariat of Agriculture, Food Industry and Forestry and the Republic Committee for Agriculture and Forestry in the economic field from 1971 to 1990, according to the archival scientific approach of describing the documentation from the moment of its acquisition until the final storage of thematic units in adequate conditions (Fonds HRHDA-2023). A study of the history of these institutions, with a description of the structure and content of the official documentation units of the original archives, is necessary to produce a multilevel top-down description, in accordance with the General International Standard Archival Description ISAD(G) and ISAAR(CPF). The purpose of describing and organizing the Committee's business documentation was to create the HR-HDA-2023 Fonds as a valuable historical source of information from archives and official data for various researches in the field of history and economic development and research of different political and economic circumstances in the territory of the former SFRY. In this sense, the aim of this paper is to provide an insight into the creation of a comprehensive fonds which 
presents a framework of complex structures of organized thematic areas, and thus provides an additional quality source for scientific research and provides a representative example for the production of a professional paper as a preparation for taking the professional exam to acquire the professional title - archivist.

\section{RIASSUNTO}

\section{Redazione della descrizione multilivello del materiale archivistico originale con l'intento di creare il Fondo HR-HDA-2023 in conformità agli standard internazionali ISAD(G) e ISAAR(CPF)}

L'articolo riporta la redazione della descrizione del materiale archivistico originale del Segretariato della Repubblica per l'agricoltura, l'industria alimentare e le politiche forestali e del Comitato della Repubblica per l'agricoltura e le politiche forestali nell'ambito dell'economia dal 1971 al 1990, conforme all'approccio archivistico scientifico della descrizione della documentazione dal momento della sua raccolta fino all'archiviazione definitiva delle unità tematiche in condizioni stabilite (Fondo HR-HDA-2023). Le ricerche relative alla storia delle istituzioni citate, con la descrizione dell'organizzazione e del contenuto delle ufficiali unità di documenti del materiale archivistico originale, è indispensabile per la redazione della descrizione multilivello, dal generale al particolare, in conformità alle normative generali internazionali per la descrizione del materiale archivistico ISAD(G) e ISAAR(CPF). L'obiettivo della descrizione e dell'organizzazione della documentazione commerciale del Comitato era quello di creare il Fondo HR-HDA-2023 come un' importante fonte storica di informazioni provenienti dal materiale archivistico e dai dati ufficiali per poter servire a varie ricerche nell'ambito della storia e lo sviluppo economico e per le ricerche relative alla situazione politica ed economica nel territorio della ex Repubblica socialista federale di Jugoslavia. In questo senso, l'obiettivo del presente lavoro è offrire la possibilità di capire la creazione di un ampio fondo presentando il quadro delle strutture complesse degli ambiti tematici organizzati e, allo stesso tempo, rappresenta un'ulteriore fonte di qualità per le ricerche scientifiche e offre un esempio positivo della redazione di un lavoro tecnico come preparazione all'esame per il titolo di archivista. 